\title{
An Apparition of Innovational Electoral System for Islamic Democracy:
}

A Religio-Political Study for Islamic Republic of Pakistan

${ }^{*}$ Dr. Syed Aftab Alam

\begin{abstract}
The spirit of true or bad political system can be judged on the basis of transparency, accountability and peopleempowerment of its Electoral System. Socio-Political philosophy sketches a candidate for state-governing services should be chaste, learned, genial \& well-wisher of humanity and a voter should not be a constrained one. In Pakistan, by rules, an election candidate can contest even from jail, in many constituencies, being too old to death or publically alleged, corrupt, absconder. They need to win election on the power of wealth so after win, they looted public properties. Gradually, due to this coercing atmosphere, almost majority of elected members become quite selfish. Contrarily, a voter cannot vote from Jail, more than one even being so learned or capable or poise. A voter has to caste vote for any one of constant rather he/she does not like them or even a voter can't caste against them. So it is declared that Pakistani voter is constrained. Ceasing of these candidature gangs and removal of constrained-ness of Pakistani voters is the most essential phase of Pakistani Politics for a transparent, accountable and people-empowered democracy in Pakistan which is analyzed through Islamic Injunctions also. It is needed to develop such innovative Electoral System in which, a selfish person can't be a contestant and a voter should not be constrained or bound. After a thorough study of electoral frameworks of developed countries, an apparition of revolutionary electoral system has been framed in this article.
\end{abstract}

Keywords

Pakistani Democracy, Electoral System, Pakistani Voter, Transparency, Accountability and People-Empowerment

* President BWO ®, Director Alam’s Learning Institute Pakistan 


\section{Introduction}

Natural phenomenon displays that all species of this universe lives in their inhibition groups. Each species has separate laws and conducts to perform their collective and individual deeds (Ward, 2016). ${ }^{1}$ It is witnessed that all members of these societies are bound to perform their duties according to their ever designed pattern and no one can deny this natural drafted rules and regulations.

These rules and regulations are seen in nesting, breeding, flying and dying of birds. Life of jungle animals also depicts the separate but defined rules and regulations. Miniature species like germs, insects and bacteria are also bound of their 'specific rules'2 (Campbell, 2014), of birthing, housing, fighting, regenerating and reforming.

Earth has one living member which has also some pre-defined and unchanged rules and regulations in their life but along with it they have power to create, alter, accept or deny the rules and regulations. ${ }^{3}$ (Laurence Simon, 1998) This creature is not constrained or fully bound. It is empowered with the authority of developing, manipulating and sustaining the old or new laws on the basis of its knowledge, experience and observation or divine guidance.

This living member of the earthy society is human being. An empowered creature designated with knowledge, fully loaded reason, spirit and material. A self-supported, self-motivated, self-managed, self-groomed and even self-drowned ${ }^{4}$ but not constrained ${ }^{5}$ one.

The human being has different systems in all sectors of life designed on "knowledge "based on" sense-experience, observation and experiments" 6 or divine guidance ${ }^{7}$. These social, personal, moral or theological sectors have many fields in which political and economic systems are really crucial.

In present era, socio-politico-economical factor of life impacts a grand on human life ${ }^{8}$, so political scenario has put some ultimate impacts in today's world. Pakistan's geographical position, its ideological start and crucial role in past has extreme importance ${ }^{9}$ that its political system should be discussed for its benefits and drawbacks to start the research for eliminating the bad factors of its political system.

The spirit of true or bad political system can be judged or in other words "keystone of this democracy... is to enhance the transparency and accountability in the Electoral process" ${ }^{\prime 10}$. Socio-Political philosophy sketches a candidate for state-governing services should be chaste, learned, genial \& well-wisher of humanity ${ }^{11}$ and a voter should "not be a constrained" $" 12$ one. 
An Apparition of Innovational Electoral lhyā' al- 'Ulūm, Volume 20, Issue 2, System for Islamic Democracy (July-Dec 2020)

This article is going to highlight some notorious facts of Pakistani Electoral System and try to highlight the importance of its alteration or amendment for an actual democratic electoral system. This article is a try to apart an innovative democratic Electoral system for specifically Pakistani society and generally for the whole globe. The vision of an innovative electoral system is the main part of this article which conveys such practical solutions to eliminate the hijacked notorious factors of contemporary electoral system and create some revolutionary factors for a major positive change in the electoral system of Pakistan.

\section{Present Electoral System in Pakistan}

In Pakistan, the first part of electoral system is nomination of candidate. This nomination is finally understood that wealthy person like landlord (called Choudhris, Zamindars and Khans), after British Rāj incorporated with industrial and commercial professions with the help of only relation to local administration ${ }^{13}$, can spend money for election campaign so they can only be the candidate. Each member of the Pakistan understands that "politics has become a big money game"14, so at very lower level like councilor if any clan has handful number of votes and wants a seat in government office then they nominate wealthy person. This is a rare chance that a gentle or poor person is recommended for nomination but if happened, there would be a strict condition from the wealthy members of the family-community that they will spend money in election campaign if the winner will return their money after having chair in government office through contracts or monetary favors throughout his tenure. On the other hand, at national or provincial level politics, only landlords now established in modern status like commercialists and industrialists can take part in political scenario. ${ }^{15}$

The second step is nomination of candidate by political parties. This is again seems a market of dialect. The big political parties has big membership fee. They made planning at provincial or national level. They are managing seats through barter system with other political parties from the last tenure of government. They made campaigns, maintain party offices and pay salary to staffs throughout the four years so a lot of expenses has been committed ultimately they need big bags to settle those expenses. This nomination is allotted to the candidate through the "party ticket fee"16 in the constituency. This ticket has a worth because they can settle with other parties i.e. seat adjustment ${ }^{17}$ before election by paying different types of remedies. Each remedy has its worth which has to pay by the candidate, 
willing nomination of the political party through its election ticket. On record, all "Election Expenses"18 are managed as per the rules and regulations of election commission of Pakistan.

The third step of electoral system in Pakistan is election management through kidnapping of opposite candidate, launching First Information Report of non-bail able offence against opponent or murder of other candidate at lower level of election. On the other hand, at national and provincial assembly election, big parties' "candidate captured the local polling station and stuffed the ballot box." "Feared harassment" and "not enough police protection" for polling officers create such situation due to "weakening institutions of ECP, the Police and the Judiciary" . All of these crucial performances required money so at this step also, money has an important role in Pakistani election.

The fourth step in election is purchase of votes through sending bags of utility items in the name of election charity. This charity continues only for two to three months prior to Election Day. It is very fruitful in poor areas of rural and even urban parts of Pakistan where people are less educated and less facilitated by government. It is due to Pakistani political research depicts it in such words "In a clientelistic environment, the votes of less educated people tend to be cheaper to purchase by candidate" ${ }^{20}$. In Pakistan especially in Punjab, "money to fund expensive campaigns (in which votes were purchased with cash and minor infrastructure projects) and muscle power to fight rivals" ${ }^{21}$. So there are many other ways of election campaign like promises with youth for jobs, promises of decisions in clan matters, paying visits at death or marriage ceremonies with morning and smiling faces and status-co gifts, arrangements of election managers to help poor voters in form of money with the exchange of National Identity Cards till the Election Day, making of streets and erecting of electric poles through candidates own pocket. Printing of election hoardings, flexes, banners, pamphlets, caps, bags, shirts, badges and flags with supporters name to maintain the election expenses in the eye of election commission.

In short, each step demands abundant wealthy expenses in present Pakistani Electoral system. So wealth spending and ultimately wealth collection is the center focus of Pakistani political system.

\section{Electoral Rules for Politicians}

It is natural that "human have been attempting to acquire more and more wealth" 22 so each wealthy politician tries to snatch or adjust wealth and assembly seats from others and capture with in its own family. As Patil 
discussed, "Pakistan has been controlled by corrupt political elites who have failed to address the real social development" ${ }^{23}$. These politicians in assemblies become qualified to build and approve rules and regulations for next election so they establish such rules and regulations for elections that no one other than their families can participate or win these elections.

They develop and approve such rules for politicians that a candidate can participate in election even being in jail, in more than one constituency, even being too old to retire or even declared bankrupt rather enjoying properties of billions.

A candidate in jail collects a huge sympathy in masses so this is a non-expansible way of election winning. There are some evidences that some intelligent politicians went to jail before election with preplanned rituals and ultimately they win the election ${ }^{24}$. Second rule is that a politician can be a candidate in two or three constituencies at any National or Provincial assembly seats ${ }^{25}$ at a time so that a clear chance should be in his hands to win in any constituency.

Another very important element for politician is that they have no retirement age. They can take part in political matters and hold some direct political government offices also in any age even after official government retirement age. Provisions as to member of Majlis-e-Shūró (Parliament) conveys minimum age limit as 25 years but upper age limit is not described $^{26}$. There are many examples that Pakistani politicians are declared bankrupt but they participate in election after fulfilling some brittle formalities ${ }^{27}$. They got expenses of election from government and became assembly members of the government for erase of bankrupt status for others also.

After winning the election, they got such authorities that can be seen in these words, "No member shall be liable to any proceeding in any court in respect of anything said or any vote given by him in Majlis-e-Shūrá and no person shall be so liable in respect of the publication by or under the authority of Majlis-e-Shūró to any report, paper, votes or proceeding". ${ }^{28}$ In some other words, "The validity of any proceeding in Majlis-e-Shūró shall not be called in question on the ground of any irregularity of procedure." 29 Besides these, there are many other illogic provisions that a member of Majlis-e-Shūró can remain absent for 40 consecutive days without any notice from the house and can remain absent more than 40 days with a leave intimation. $^{30}$

Resultantly, Pakistan "is a society where the majority of the population feels powerless" 31 and a monopoly of past politicians is going on 
to strengthen their future in the scenario of daughters and sons as assembly members of Pakistan. Although they are qualified or not, experienced or not, capable or not, earned degrees or not and students of foreign universities or only labeled. To strengthen this system, the elite class has established a silent gang. This gang of assembly seat handlers in Pakistani elite class has developed such demarcation between masses and the gang that no gentle citizen can take stand against their system. Previous politicians had created such carpeted path for their sons and daughters that they can become the member of national and provincial assemblies without any hustle and bustle. In conclusion, approximately all election winners are free to snatch public properties and fulfill their expenses by hook or by crock. Gradually, due to this coercing atmosphere, almost majority of elected members become quite selfish.

In short, In Islamic Republic of Pakistan, election candidates can participate in election even being in jail, in more than one constituency, even being too old to retire or even declared bankrupt enjoying properties of billions. Apparently, core requirement of candidature is seems only wealth. Political parties sale their tickets and even seats on interest based collusions. A gang of Assembly Seat Handlers in Pakistani elite class has been established and it developed such demarcation between masses and the gang that no gentle citizen can take stand against their system. Resultantly, approximately all election winners are free to snatch public properties and fulfill their election expenses by hook or by crock. Gradually, due to this coercing atmosphere, almost majority of elected members become quite selfish.

\section{Electoral Rules for Voters}

Governing services of any country need highly caliber, experienced and learned persons of nation but in Pakistani electoral system, there is a grand hindrance that no working professor, commissioner or general can become a candidate of national or provincial assemblies in election. It is a general vision that a professor has a highly learned status in society. Professors read the pulse of its nation and convey a sophisticated and accurate path of national development and growth. But no in-service experienced, learned and well-wisher professor can participate in election of National or Provincial assembly of Pakistan. The same in the sector of pass outs of public service commissions and forces' dignitaries. No one from these two grand communities of Pakistani nation can be nominated for 
serving Pakistani nation in assemblies. So there is an alarming drawback of Pakistani nation that cream of nation cannot serve them in its assemblies. ${ }^{32}$

"The first key element is the 'Voter' namely the 'People of Pakistan', voter have the absolute power to elect the 'rulers of the state' ${ }^{33}$. In Pakistan, such electoral system has been established that voter has least importance. It comes into notice of politicians just five months prior to the Election Day. Voter of Pakistani society is less educated ${ }^{34}$, badly bogged in terrorism threats $^{35}$, poor economical frustration, interlaced in corruption and lawlessness ${ }^{36}$ and trapped in so-called race of being developed.

In present Pakistani electoral system, the voter is fully constrained because he has to caste his/her vote in favor of any one standing candidate. On the other hand, if Pakistani voter does not caste his/her vote, there is no harm to the candidate because there is no law that if the casting is low at such rate, the election would be re-ballot. There is no any portion in ballot that if a voter did not like to vote any contesting candidate, he/she can mark the portion, and election commission can count that the voters of the constituency do not like these candidates and want another candidate. There are no provisions displays that if a member of assembly does not perform his/her duties properly, the voters of the constituency can remove him/her as their representative in the assembly.

In short, voter is just a puppet in the hands of crude electoral system. The history of political elections in Pakistan depicted many incidents that during ballot counting, more number of votes was found in ballot boxes than the constituency has total number of voters. Moreover that Election Commission of Pakistan's decision to advise over four million Pakistanis to go to Pakistan to cast their ballot is totally 'illogical and unpractical'. ${ }^{37}$ As it is discussed earlier, the experienced politicians had developed such system 'to safeguard the rights and interests of fellows' 38 and the need of voter would be as a drama. So the voter is compelled ${ }^{39}$, compelled to attain short and little benefits against his/her vote.

It is in practice that the votes from jail do not include in first counting. Pakistani professor, army general, secretary has one vote in present electoral system which is just equal to the vote of an illiterate and nomad citizen of Pakistan.

Pakistani voter cannot caste his/her vote in favor of such learned, gentle and capable Pakistani citizen who is witnessed by him/her as a perfect person in his social life, excellent in his official duties and proficient for national or international duties because the person could not be a candidate in election according to the provisions of law ${ }^{40}$. The voter is constrained to 
cast his vote in favor of any contesting candidate or to spoil his vote through non-casting.

In short, On the other hand, a vote from jail is not included in first counting, a voter, although extremely learned and capable to decide the international matters accurately, and a voter, totally illiterate and dull, has both only one vote. Above all, a voter has to caste his/her vote in favor of any one candidate besides this that he/she knows that the candidate is corrupt and selfish because if he/she did not caste his/her vote, the candidate can win. A voter can't cast his/her vote in favor of the citizen whom he/she understands that the person is capable and real well-wisher of Pakistan. So it is declared that Pakistani voter is constrained.

\section{Solution of this Situation}

Solution of this electoral system is lies in the removal of constrainedness of Pakistani voter. The solution needs a quite reverse and different electoral system. The electoral system should have such apparitional shape.

1. Voter should be free to elect any Pakistani citizen who can be his/her representative in national or provincial assemblies.

2. Voter should have clear and announced authority to remove his/her representative in national or provincial assemblies.

3. Voter should have complete awareness and interjection with his/her representative in national or provincial assemblies.

4. Any gentle, truthful and faithful citizen of Pakistan can be the representative in national or provincial assemblies of a Pakistani voter.

5. The electoral system should be continued all the year so that election procedure should be refrained by and by.

6. The constituencies should be narrow, fixed and finalized so that ambiguity about constituencies should be removed and voter has clear vision about his/her representative.

7. There should be a chain of councils of learned and experienced citizens at all stages of communities.

In short, in this electoral system, no one can present him/herself as an candidate but a voter can elect any member of its constituency with his/her absolute free will rather his/her candidate is serving in public or private department or running a business or indulging in any other legal social activities.

As an overview of this electoral system, it will, immediately, purge out the first crystal that full empowerment of election goes to the hands of 
An Apparition of Innovational Electoral lhyā' al- 'Ulūm, Volume 20, Issue 2, System for Islamic Democracy

(July-Dec 2020)

Pakistani voter which is the basic requirement of people-empowered democratic political system. Through this system, elected members in state assembly will be from different fields of life so they have a great and vast exposure of life handling variety of matters. On the other hand, voter of each level will deal each other's for a specific time then cast their vote in favor of any other member so they have a clear picture of candidate whom he/she decides to vote and on other end, there will be no election expenses, no party ticket expenses and no intelligence for searching and scandalizing the defects of other candidates due to non-submission of candidature nomination papers, etc.

\section{Conclusion: Apparitional View of Innovative Electoral System in Pakistan}

In present jaded political situation, there should be quite innovative and 'unexpected" ${ }^{41}$ pattern. First, it is concluded that there should be such electoral system that no politician can present him/herself as a candidate. Each desiring candidate can visit his/her constituency and prove that he/she is the best masses representative and member of his/her constituency should cast voter in his/her favor but he/she cannot be nominated as contesting candidate. Through this practice, the contestant has not to spend money for election campaigns or to buy the votes but just to prove that he/she is the best representative due to his/her behavior, knowledge, experience, attitude and faithfulness towards their people.

According to the researchers' vision, second, important aspect of this new electoral system should be that a voter can cast his/her vote in favor of any member of the constituency rather his/her representative is working as professor, army general, public servant or businessman. If his/her representative wins the election, the representative will relieve from his/her present job and can join as elected member of the assembly for the specific tenure.

There should be smallest constituencies that each voter can personally deal with his/her representative to know. There should be a hierarchy of assemblies and members of each lower will elect the members of higher assemblies. A specific period of time should be given to each assembly to communicate and deal with each other and then the next stage of election should occur.

A voter has the power to caste more than one vote as per his qualification, experience and expertise. For example, a common person has power of one vote but a graduate of college has power of two votes and a 
An Apparition of Innovational Electoral lhyā' al- 'Ulūm, Volume 20, Issue 2, System for Islamic Democracy (July-Dec 2020)

$\mathrm{PhD}$ degree holder has the power of three votes. The same, a government officer from BPS 17-19 has the power of one more vote and BPS 20 and above has the power of two more votes. A businessman paying tax to the government from 5-10 lacs has the power of one more vote and a taxpayer from 10-30 lacs has more two votes, similarly who pays taxes to the government more than 30 lacs previous years has power of more three votes. A social worker having government national award has the power of two more votes.

This electoral system will, immediately, purge out the first crystal that full empowerment of election goes to the hands of Pakistani voter which is the basic requirement of people-empowered democratic political system. Through this system, elected members in state assembly will be from different fields of life so they have a great and vast exposure of life handling in variety of matters.

On the other hand, voter of each level will deal each other's for a specific time then they will cast their secret vote in favor of any other member so they have a clear picture of candidate whom he/she decides to vote and on other end, there will be no election expenses, no party ticket expenses and no intelligence for searching and scandalizing the defects of other candidates due to non-submission of candidature nomination papers, etc.

Of course, it is quite an innovative idea, and it will be discussed and furnished in next research study.

\section{References:}

${ }^{1}$ Ward Ashley \& Webster Mike, Sociality: The Behavior of Group-Living Animals, Switzerland: Springer International Publishing, 2016, p.176

${ }^{2}$ Campbell Gordon Lindsay, (ed.) The Oxford Handbook of Animals in Classical Thought and Life, (United Kingdom: Oxford University Press, 2014), p.218

${ }^{3}$ Laurence Simon, Psychology, Education, Gods, and Humanity, (Westport: Preager Publishers, 1998), p.51

4 "The Index: Weekly Paper devoted to Free Religion", (Boston: The Library of the University of Michigan, 1875), p.3

5 Gillespie Michael Allen, "Nihilism Before Nietzsche", (Chicago and London: The University of Chicago Press, 1994), p.96 
An Apparition of Innovational Electoral lhyā' al- 'Ulūm, Volume 20, Issue 2, System for Islamic Democracy

(July-Dec 2020)

6 "215 Boston Studies in the Philosophy of Science: The Reality of Unobservable, Observability, Un-observability and Their Impact on the Issues of Scientific Realism”, Edited by Evandro Agazzi and Massimo Pauri, (London: Kluwer Academic Publishers, 2000), p.154

${ }^{7}$ Johann Wolfgang Goethe, "Goethe's Message to the $21^{\text {st }}$ Century: Islam is the Rescue for Humanity", (London:), p.5

8 Hans Gunter Brauch, Ursula Spring, at al. "Coping with Global Environmental Change, Disasters and Security: Threats", (London: Springer International Publishers, 2011), p.76

9 "Pakistan Defense Review" (Pakistan: Pakistan Army, 1994), Vol. 6, pp. 78-81

10 "Deepening Democracy: A Decade of Electoral Interventions by Civil Society Groups", (Bangalore: Public Affair Center, 2006), p.3

${ }^{11}$ Ann Holiness', "The New York Mirror: Devoted to Literature and Fine Arts", (Michigan: The University of Michigan, 1833), Vol. 11, p.99

12 Smith Aric R.A.N., "The Unchanging American Voter", (London, Los Angles and Berkeley: University of California Press,1989), p.149

${ }^{13}$ Muhammad A. Qadeer, "Pakistan: Social and Cultural Transformations in a Muslim Nation", chapter The State and Village Power Structure, (London and New York: Routledge, Taylor and Francis Group, 2006), p. 124

${ }^{14}$ Ikramul Haq, "Pakistan: Drug Trap to Debit Trap", (Lahore: Lahore Law Publication, 2003), p. 23

${ }^{15}$ Ibid 1, p. 179

${ }^{16}$ IDEA International, "Political Parties in South Asia: The Challenge of Change”, (India: IDEA International, 2007), p.95

${ }^{17}$ Institute of Policy Studies, "Pakistan Political Perspective", (Islamabad: IPS, 2005), Vol. 14, Issue 6, p.32

${ }_{18}$ Pakistan: Electoral, Political Parties Laws and Regulations Handbook, Strategic Information, Regulations, Procedures, Chapter VI Election Expenses, (Washington DC and Pakistan: International Business Publications, 2016), p. 200

${ }^{19}$ Nicolas Martin, "Politics, the Landlord and Islam in Pakistan: Exploring the Political in South Asia", (New York: Routledge, 2016) p.144

20 Kamiljon T. Akramov, Sarfraz Qureshi, Regina Birner and Bilal Hassan Khan, "Decentralization, Local Government Elections and Voter Turnout in Pakistan", IFPRI Discussion Paper 00754, (Islamabad: Development Strategy and Governance Division, March 2008), p.16 
An Apparition of Innovational Electoral lhyā' al- 'Ulūm, Volume 20, Issue 2, System for Islamic Democracy

21 Anastasis Piliavsky, "Patronage as Politics in South Asia", (Delhi: Cambridge House Ansari Road Daryaganj, 2014), p.137

22 Alam Macmillan Arr, "The Little Book of Life",(Lahore: books.google.com.pk), p. 580

23 Amitendu Patil, "South Asia: Beyond the Global Financial Crises", (Singapore: World Scientific Publishing Co. Pte. Ltd., 2011), p. 124

${ }^{24}$ Kalim Bahadur, "Democracy in Pakistan: Crises and Conflicts", (New Delhi: Har-Anand Publications Pvt. Ltd, 1998), p.149

${ }^{25}$ Ibid, p. 108

26 Institute of Policy Studies, "Pakistan: Country Study Guide", (Washington: International Business Publication, 2013), Vol. 1, p. 135

2727 "Near East/ South Asia: Report", Issue 85005 (London: Foreign Broadcast Information Service, 1985), p. 130

${ }^{28}$ Ibid 3, Section 66 (1), p. 137

${ }^{29}$ Ibid 3, Section 69 (1), p. 139

${ }^{30}$ Ibid 3, Section 64 (2), p. 135

31 Pamela Constable, "Playing with Fire: Pakistan at War with Itself", (Random House Publishing Group, 2011), p.87

32 Ibid, Section 63 (e, k, o, q), p. 136-41

${ }^{33}$ Ali Abbas Hassanie, "Democracy in Pakistan: Crisis, Conflicts and Hope for a Change”, (Bloomington: Authors House, 2013), p. 22

${ }^{34}$ Ibid, p. 12

${ }^{35}$ Ibid, p. 27

${ }^{36}$ Ibid, p. 62

${ }^{37}$ Ali Abbas Hassanie, "Democracy in Pakistan: Crisis, Conflicts and Hope for a Change”, (Bloomington: Authors House, 2013), p. 87

${ }^{38}$ Ibid, p. 94

${ }^{39}$ Ibid, p. 101

${ }^{40}$ Institute of Policy Studies, "Pakistan: Country Study Guide", Section 63 (e, k), (Washington: International Business Publication, 2013), Vol. 1, pp. 136-137

${ }^{41}$ "Unexpected" because the cunning mind politicians cannot draw any illegal or negative way to capture the positivity of the system and masses of the society can get a handful time to draw the benefits of the innovative system. 